\title{
Green Synthesis and Application of ZSM-5 Zeolite
}

\author{
O. Chen, ${ }^{a}$ S.-C. Liu, ${ }^{a}$ P.-Q. Zhang, ${ }^{a}$ and S.-Q. Zhenga,b, \\ a Department of Chemistry and Chemical Engineering, Hunan Institute of Science and \\ Technology, Yueyang 414006, Hunan, P.R. China \\ b Hunan Province Key Laboratory of Speciality Petrochemicals Catalysis and Separation, \\ Yueyang 414000 , Hunan, P.R. China
}

This work is licensed under a

\begin{abstract}
A ZSM-5 molecular sieve composite with a wide pore prepared by the solid phase in-situ synthesis method and fluid catalytic cracking, and an FCC catalyst additive prepared by the same ZSM-5 molecular sieve for increasing the amount of light olefin yield were investigated. The samples were characterized by XRD, $\mathrm{N}_{2}$ adsorption/desorption, $\mathrm{SEM}$, and $\mathrm{NH}_{3}-\mathrm{TPD}$, respectively. The results showed that the structure of the ZSM-5 molecular sieve composite prepared by solid phase in-situ synthesis method was pure MFI-type zeolite material. The crystallinity of ZSM-5 molecular sieve was $59.8 \mathrm{wt} \%$. The synthesized ZSM-5 molecular sieve had more acid content and a wide-pore structure. The average pore size was $5.9 \mathrm{~nm}$, and BET specific surface area and micropore specific surface area of sample were $213 \mathrm{~m}^{2} \mathrm{~g}^{-1}$ and $124 \mathrm{~m}^{2} \mathrm{~g}^{-1}$, respectively. The evaluated results indicated that the FCC catalyst additive had good selectivity for LPG, propylene, and butene, increasing propylene and butene yields by $2.28 \mathrm{wt} \%$ and $2.15 \mathrm{wt} \%$, respectively, as well as had better heavy oil cracking capability and coke selectivity.
\end{abstract}

\section{Keywords}

ZSM-5 zeolite, in-situ technology, solid phase synthesis method, FCC catalyst additive, increasing light olefin yield

\section{Introduction}

As the simplest olefin compounds, ethylene and propylene are important crude oil cracking products in industry. Light olefins are used to develop a variety of organic products, which play an important role in organic synthesis. ${ }^{1}$ Among them, the production of ethylene has become an important indicator in measuring the development of the national petrochemical industry. Polypropylene synthesized by propylene polymerization has become the main material for the preparation of wood, metal materials, and other building materials, paper, and other necessities of life. ${ }^{2-3}$ Although the production of olefins in China has increased significantly, the market demand and supply are yet to be realized. The data show that, in 2017, the polyethylene import dependence in China was $46.27 \%$, proving that China was still unable to achieve self-sufficiency. The preparation of light olefin content by naphtha cracking was the main method.

Fluid catalytic cracking has been the core technology of heavy oil processing in modern oil refining enterprises. With the aggravating trend of heavier and deteriorated crude oil, ${ }^{4}$ the total amount of heavy metals, carbon residue, sulphur, nitrogen, and other heteroatom compounds had been significantly increased. Residual oil is more difficult to deal with in the FCC unit, and the heavy metal content of the equilibrium catalyst has been significantly increased, especially the nickel and vanadium content. In addition, the reduction in conversion and the increase in coke and dry gas yields had also brought about a series of

${ }^{*}$ Corresponding author: Dr Shu-Qin Zheng

Email: zhengshuqin37@163.com problems to heavy oil cracking, which has a great impact on the economic benefits of refineries. Moreover, in the process of heavy oil catalysis, the production capacity of petroleum cracking was greatly increased compared with that in the past, due to the emergence of FCC catalyst. FCC catalyst has also become an important part of catalytic cracking technology. ${ }^{5}$ With its unique pore structure, zeolite has become an indispensable catalytic material in the petrochemical industry. ${ }^{6-11}$ However, the process of traditional hydrothermal synthesis of ZSM-5 zeolite has many inevitable shortcomings, such as low utilization of the reactants, wastewater and organic waste liquid, and other resources waste and pollution. Therefore, the green synthesis of ZSM-5 molecular sieve has become one of the studies and development hotspots of major oil refining institutions at home and abroad. ${ }^{12-15}$

Natural minerals, such as kaolin and diatomite, have been used as green raw materials for synthesis of ZSM-5 molecular sieve. It is reported that ZSM-5 molecular sieve can be crystallized in hydrothermal alkaline solution by acid dealumination of calcined kaolin with hydrochloric acid. ${ }^{16-17}$ Zhang et al. ${ }^{18}$ reported a hierarchical porous ZSM-5 molecular sieve prepared by in-situ crystallization using diatomite as silicon source, sodium aluminate as aluminum source, and nucleation centers as directing agent. In this experiment, the optimum synthesis conditions were determined, and the aromatization activity and anti-coking ability of this molecular sieve were greatly improved. In addition, Liu et al. ${ }^{19}$ also reported a preparation method of ZSM-5 molecular sieve with sub-microporous structure, which can be synthesized in a small amount of water solvent through the induction of ZSM-5 crystal seed with hydrated compounds and illite clay as raw materials. The test 
of toluene disproportionation proved that the molecular sieve had high catalytic activity.

In this paper, ZSM-5 molecular sieve was synthesized by the green method of solid phase in-situ synthesis, and FCC catalyst additive of increasing amount of light olefin was prepared from this synthesized ZSM-5 molecular sieve. The physicochemical properties and catalytic performance of samples were tested, and the differences in catalytic performance of FCC catalyst additive prepared by the green method of solid phase in-situ synthesis and traditional in-situ hydrothermal method were investigated, respectively. The new method can improve the utilization rate of the reactor, the amount of wastewater was greatly reduced, and produced no organic wastewater.

\section{Experimental}

\subsection{Materials}

The following materials were used in this study: Kaolin (China kaolin company), water glass (Changsha Wanfang Chemical Co. Ltd., $w_{\mathrm{SiO}_{2}}=20.7 \%, w_{\mathrm{NaO}_{2}}=6.8 \%$ ), sodium hydroxide (Tianjin Chemical Reagent Factory, reagent grade $\geq 98$ wt $\%, A R$ ), sulphuric acid (Tianjin Chemical Reagent Factory, reagent grade $\geq 98 w t \%, A R), Z S M-5$ molecular sieve (Zibo Qi Chuang Chemical Technology Development Co. Ltd., synthesis by traditional gel technology, the crystallinity $=94 \%, n_{\mathrm{SiO}_{2}} / n_{\mathrm{Al}_{2} \mathrm{O}_{3}}=240$, denote by CZ). Silica (Guangzhou liben rubber raw materials Co. Ltd., $\mathrm{SiO}_{2}, 99$ wt\%). A commercial FCC catalyst was used as the base catalyst. The catalyst was developed by the Research Institute of Petroleum Processing in Beijing.

\subsection{Pre-treatment of kaolin}

Before kaolin is involved in the synthesis, it needs to be activated. Kaolin was mixed with water to make slurry, sprayed, and dried to obtain kaolin microspheres. The microspheres were then calcinated at $800{ }^{\circ} \mathrm{C}$ for $4 \mathrm{~h}$, and the activation was completed.

\subsection{Traditional in-situ hydrothermal synthesis of ZSM-5 molecular sieve}

The steps of synthesis of ZSM-5 molecular sieve were as follows: sodium silicate, sodium hydroxide solution, distilled water, kaolin microsphere, and crystal seed (5 wt\% ZSM-5) were successively added into beaker and stirred evenly. The molar ratio of the reaction process was $n\left(\mathrm{SiO}_{2}\right) / n\left(\mathrm{Al}_{2} \mathrm{O}_{3}\right)=15, n\left(\mathrm{Na}_{2} \mathrm{O}\right) / n\left(\mathrm{SiO}_{2}\right)=0.30, n\left(\mathrm{H}_{2} \mathrm{O}\right) /$ $n\left(\mathrm{Na}_{2} \mathrm{O}\right)=200$. After adjusting the $\mathrm{pH}$ value to $11 \sim 12$ by sulphuric acid, it was transferred to a stainless steel reactor with lining of polytetrafluoroethylene, and constant reaction temperature at $150{ }^{\circ} \mathrm{C}$ for $72 \mathrm{~h}$. After reaction, it was filtered and washed with distilled water. After drying in the oven, the crystallization product was obtained and recorded as IZ.

\subsection{Green solid phase in-situ synthesis of ZSM-5 zeolite}

The method differs from the aforementioned method in that it requires no addition of distilled water. The specific operations were as follows: kaolin microspheres, water glass, silica $\left(\mathrm{SiO}_{2}, 99\right.$ wt\%), and crystal seed (5 wt\% ZSM-5) were placed in the mortar and ground. The $\mathrm{pH}$ value of the reactant was adjusted to $11 \sim 12$ by sulphuric acid. At this time, the appearance of the system was wet solid sand. The above materials were ground for $20 \mathrm{~min}$, and then transferred to the reactor, where they were crystallized at a constant temperature of $150{ }^{\circ} \mathrm{C}$ for $80 \mathrm{~h}$. After the reaction, it was washed with pure water, and then dried. The final product was recorded as GZ.

\subsection{Preparation of FCC catalyst additive}

The IZ and GZ were exchanged several times with approximately 10 to 30 weight percent of ammonium chloride to replace the sodium at room temperature for $30 \mathrm{~min}$, respectively. The IZ and GZ were exchanged with an aqueous solution of lanthanum chloride for $30 \mathrm{~min}$, respectively. The FCC catalyst additives were filtered, washed, and calcined at $600{ }^{\circ} \mathrm{C}$ with $100 \%$ steam for $2 \mathrm{~h}$, respectively. They were recorded as ICD and GCD, respectively.

\subsection{Characterization}

X-ray diffraction: crystallinity and phase of samples were recorded on a Rigaku Ultimi IV diffractometer using Cu-k $\alpha$ radiation $(\lambda=1.54056 \AA)$ operating at a tube voltage of $40 \mathrm{kV}$, and a tube current of $30 \mathrm{~mA}$. The samples were scanned at a speed of $0.2^{\circ} \mathrm{min}^{-1}$. The relative crystallinity was calculated according to the following equation:

$$
\alpha=\frac{I_{2 \theta}}{I_{2 \theta, 0}} \cdot \alpha_{0}
$$

where, $I_{2 \theta}$ and $I_{2 \theta, 0}$ are the sum of the characteristic peak heights of the measured sample and the standard sample between $22.5^{\circ}$ and $25^{\circ}$ in $2 \theta$, respectively; $\alpha_{0}$ is the relative crystallinity of standard ZSM-5.

$\mathrm{N}_{2}$ adsorption/desorption methods: The specific surface areas, pore volumes, and pore size distributions were measured on an ASAP 2020 sorptometer using adsorption and desorption isotherm plots at $-196{ }^{\circ} \mathrm{C}$. Prior to the measurement, the samples were degassed at $350{ }^{\circ} \mathrm{C}$ for $12 \mathrm{~h}$.

SEM: The morphology and size of the samples were determined using scanning electron microscopy (SEM) (JEOL JSM-6360) after coating with an Au evaporated film.

$\mathrm{NH}_{3}$-TPD: The acid strength of ZSM-5 was measured by the American Max AutoChem II 2920 fully automatic temperature programmed chemical adsorption instrument. 


\subsection{Microactivity tests (MAT)}

The activity of the catalyst additive was investigated using a microactivity test unit. The MAT conditions were as follows: reactor temperature $460{ }^{\circ} \mathrm{C}$, reaction time $70 \mathrm{~s}$, weight hourly space velocity (WHSV) $15 \mathrm{~h}^{-1}$, and catalyst-to-oil mass ratio of $3: 2$. Prior to the MAT test, the fresh catalyst additive was steam-deactivated at $800{ }^{\circ} \mathrm{C}$ for $4 \mathrm{~h}$ or $17 \mathrm{~h}$ with $100 \%$ steam.

\subsection{Catalytic properties evaluation}

The catalytic performance was tested on an advanced catalyst evaluation bench unit (ACE, Kayser Corp.) with a mixture of $70 \%$ vacuum gas oil (VGO), and $30 \%$ vacuum tower bottom (VTB) as the feed. Its properties are listed in Table 1 . Three catalysts of the base catalyst, the base catalyst and ICD mixed at a 90:10 weight ratio, the base catalyst and GCD mixed at a 90:10 weight ratio was initially steam-deactivated at $800{ }^{\circ} \mathrm{C}$ for $17 \mathrm{~h}$ with $100 \%$ steam, respectively. The reaction conditions: reactor temperature $520{ }^{\circ} \mathrm{C}, \mathrm{WHSV} 19 \mathrm{~h}^{-1}$, and catalyst-to-oil mass ratio $7: 0$.

Table 1 - Properties of the feedstock oil

\begin{tabular}{c|c}
\hline Items & Feedstock oil \\
\hline density $\left(50{ }^{\circ} \mathrm{C}\right) / \mathrm{g} \mathrm{cm}^{-3}$ & 0.9222 \\
\hline viscosity, $\left(50^{\circ} \mathrm{C}\right) / \mathrm{mm}^{2} \mathrm{~s}^{-1}$ & 79.48 \\
\hline Conradson carbon residue $/ \mathrm{wt} \%$ & 3.8 \\
\hline sulphur $/ \mathrm{wt} \%$ & 1.93 \\
\hline $\mathrm{Ni} / \mu \mathrm{gg}^{-1}$ & 5.58 \\
\hline $\mathrm{V} / \mu \mathrm{gg}^{-1}$ & 6.71 \\
\hline Type analysis/wt $\%$ & \\
paraffins & 56.49 \\
aromatics & 30.01 \\
pectin & 11.58 \\
asphaltene & 1.92 \\
\hline
\end{tabular}

\section{Results and discussion}

\subsection{Green in-situ synthesis of ZSM-5 zeolite}

Zeolite can be prepared using a conventional gel synthesis method or in-situ technology. In the latter method, the composites containing the active components and matrix are prepared by one step, and the thermal stability of the material is more prominent than the former.

In this experiment, the conditions of the green in-situ synthesis of ZSM-5 molecular sieve were $n\left(\mathrm{SiO}_{2}\right) / n\left(\mathrm{Al}_{2} \mathrm{O}_{3}\right)=$ $=4.2, n\left(\mathrm{Na}_{2} \mathrm{O}\right) / n\left(\mathrm{SiO}_{2}\right)=0.18 \sim 0.22, n\left(\mathrm{H}_{2} \mathrm{O}\right) / n\left(\mathrm{Na}_{2} \mathrm{O}\right)=$ $=30$, reaction time $80 \mathrm{~h}$, reaction temperature $150{ }^{\circ} \mathrm{C}$, and the seed crystal addition amount $5 \mathrm{wt} \%$ of the kaolin microspheres.

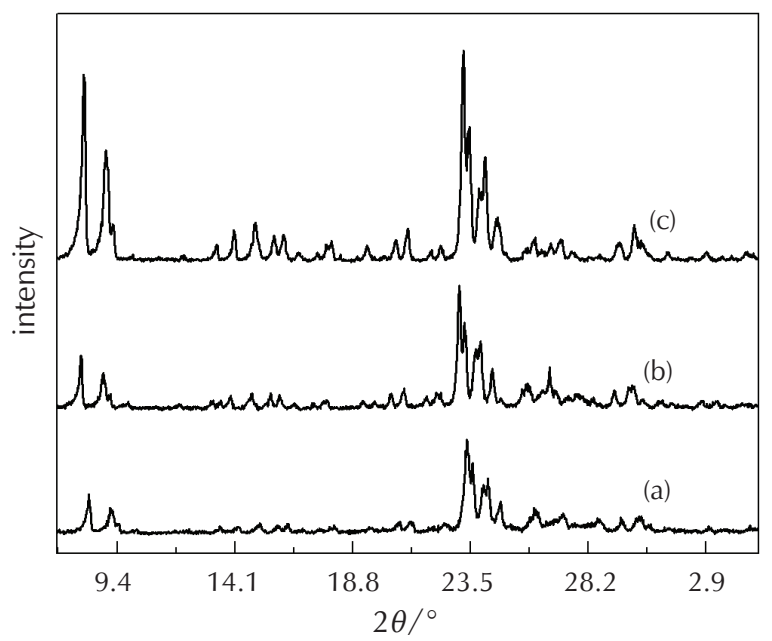

Fig. 1 - XRD pattern of ZSM-5 molecular sieve (a) IZ, (b) GZ, (c) $\mathrm{CZ}$

Fig. 1 shows the XRD patterns of the ZSM-5 molecular sieve synthesized by green in-situ synthesis method, traditional in-situ hydrothermal synthesis method, and traditional gel technology. It may be seen that the XRD patterns are typical of zeolite MFI. The results show that the structure of the samples prepared by three methods is pure MFI-type zeolite material. By the green method of solid phase in-situ synthesis, at aforementioned reaction conditions, the crystallinity of GZ was $59.8 \%$, and the crystallinity of IZ was $56.9 \%$, where the crystallinity of ZSM-5 synthesized by the green method was slightly higher than that by in-situ hydrothermal method. Compared to $\mathrm{CZ}, \mathrm{GZ}$ could reach $64 \%$ of CZ. This showed that the green synthesis process possessed good crystallization ability. The research found that the residual active silicon and active aluminum in the mother liquor after in-situ hydrothermal synthesis, proved that the components of the reaction system were excessive, which might lead to the waste of resources. In the solid phase synthesis process, the silicon and aluminum sources were in full contact with the crystal seed through grinding, which increased the molecular diffusion and effective collision efficiency. At the same time, the heat generated in the grinding process can increase the growth rate of crystal nucleus, leading to shorter induction period, shorter crystallization time, and faster synthesis of the reaction than the traditional hydrothermal static system. Moreover, it can be converted to kinetic energy in the form of prompting effective particle collision to prevent particles from coming together, thus ensuring that the product had good dispersion, and consistent crystal morphology and size. Therefore, the ZSM-5 by green in-situ synthesis method had higher crystallinity.

The results showed that the isotherms of ZSM-5 zeolite synthesized by solid phase in-situ synthesis method and in-situ hydrothermal synthesis method exhibited charac- 


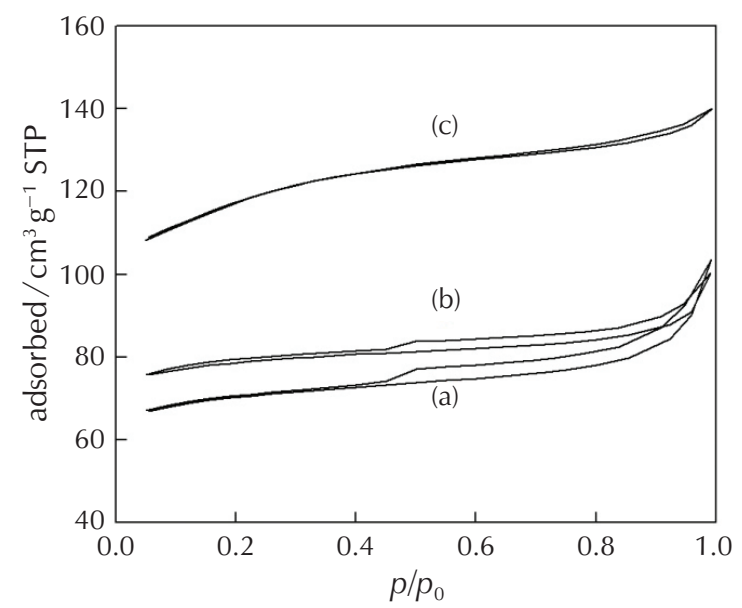

Fig. $2-\mathrm{N}_{2}$ adsorption-desorption isotherms of ZSM-5 molecular sieve (a) IZ, (b) GZ, (c) CZ

teristic type-IV adsorption/desorption. The typical type IV isotherm confirmed the presence of mesopores or macropores. At relative pressure $\left(p / p_{0}\right)$ in the range of $0.10 \sim 0.45$, the adsorption capacity increased with the increase in relative pressure, and at relative pressure $\left(p / p_{0}\right)$ in the range of $0.45 \sim 0.80$, the adsorption capacity gradually slowed down. The larger isotherm slope could be clearly seen when $p / p_{0}$ was greater than 0.8 , the adsorption capacity increased significantly, and the $\mathrm{H} 3$ hysteresis loop with a relative pressure of $0.45 \sim 1.0$ further confirmed the existence of mesoporous structure. The isotherms of ZSM-5 zeolite synthesized by traditional gel technology exhibited characteristic type-I adsorption-desorption, suggesting that the sample had more micropores and strong adsorption in the pore.

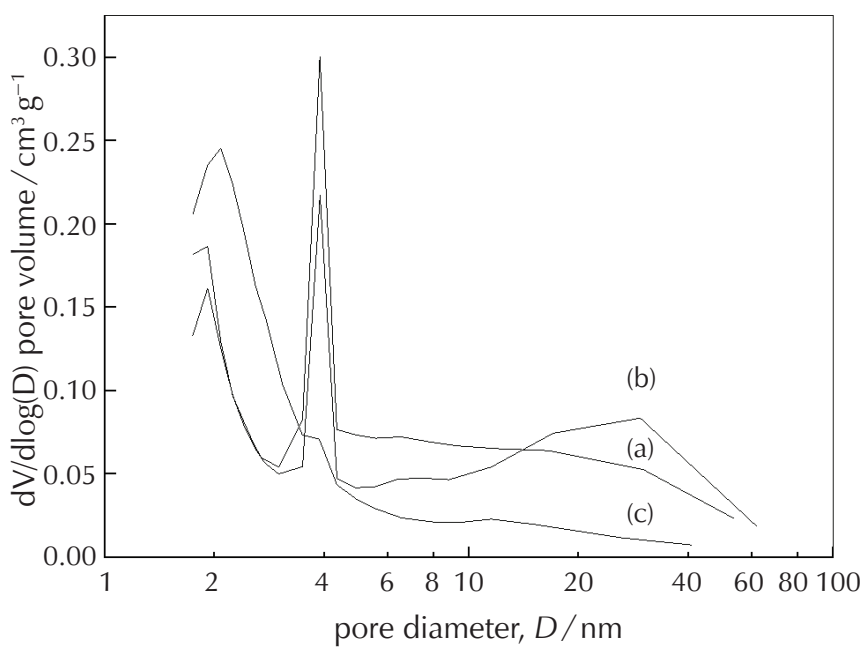

Fig. 3 - Pore size distribution of ZSM-5 molecular sieve (a) IZ, (b) GZ, (c) CZ

Fig. 3 shows the pore size distribution of ZSM-5 molecular sieves. The distribution of GZ was concentrated at 2, 4, and $32 \mathrm{~nm}$, indicating that the GZ was a mesoporous ma- terial. The distribution of IZ was concentrated at 2,4 nm, and that of $\mathrm{CZ}$ was concentrated at $2 \mathrm{~nm}$. These results suggest that the ZSM-5 molecular sieve synthesis by the solid phase in-situ synthesis method had a broad pore distribution mainly associated with this synthesis process. This pore system can greatly enhance the accessibility of the catalytically active sites inside the microporous channels to larger reactant molecules, leading to accelerated diffusion of products and fewer secondary reactions that could result in the formation of dry gas and coke.

Table 2 - Pore volume and specific surface area of ZSM-5 molecular sieve

\begin{tabular}{|c|c|c|c|c|c|}
\hline \multirow{2}{*}{ Samples } & \multirow{2}{*}{$\begin{array}{c}\text { Average } \\
\text { pore size / } \\
\mathrm{nm}\end{array}$} & \multicolumn{2}{|c|}{$V_{\mathrm{p}} / \mathrm{cm}^{3} \mathrm{~g}^{-1}$} & \multicolumn{2}{|c|}{$S_{\mathrm{BET}} / \mathrm{m}^{2} \mathrm{~g}^{-1}$} \\
\hline & & Total & Micropore & Total & Micropore \\
\hline IZ & 4.9 & 0.18 & 0.06 & 196 & 115 \\
\hline $\mathrm{GZ}$ & 5.9 & 0.19 & 0.07 & 213 & 124 \\
\hline $\mathrm{CZ}$ & 3.0 & 0.22 & 0.13 & 368 & 252 \\
\hline
\end{tabular}

Pore volume and specific surface area of ZSM-5 molecular sieves are given in Table 2 . The results showed that the average pore sizes of GZ and IZ were $5.8 \mathrm{~nm}$ and $4.9 \mathrm{~nm}$, respectively, indicating that the ZSM-5 molecular sieve synthesized by the solid phase in-situ synthesis method had larger average pore size. The total pore volume and the micropore pore volume of GZ and IZ were similar. The BET specific surface areas of GZ and IZ were $213 \mathrm{~m}^{2} \mathrm{~g}^{-1}$ and $196 \mathrm{~m}^{2} \mathrm{~g}^{-1}$, respectively, the micropore specific surface areas of GZ and IZ were $124 \mathrm{~m}^{2} \mathrm{~g}^{-1}$ and $115 \mathrm{~m}^{2} \mathrm{~g}^{-1}$, respectively, while the specific surface area of GZ was higher, indicating that the properties of ZSM-5 zeolite synthesized by the green method of solid phase in-situ synthesis had more advantages. The average pore size of $\mathrm{CZ}$ was $3.0 \mathrm{~nm}$,
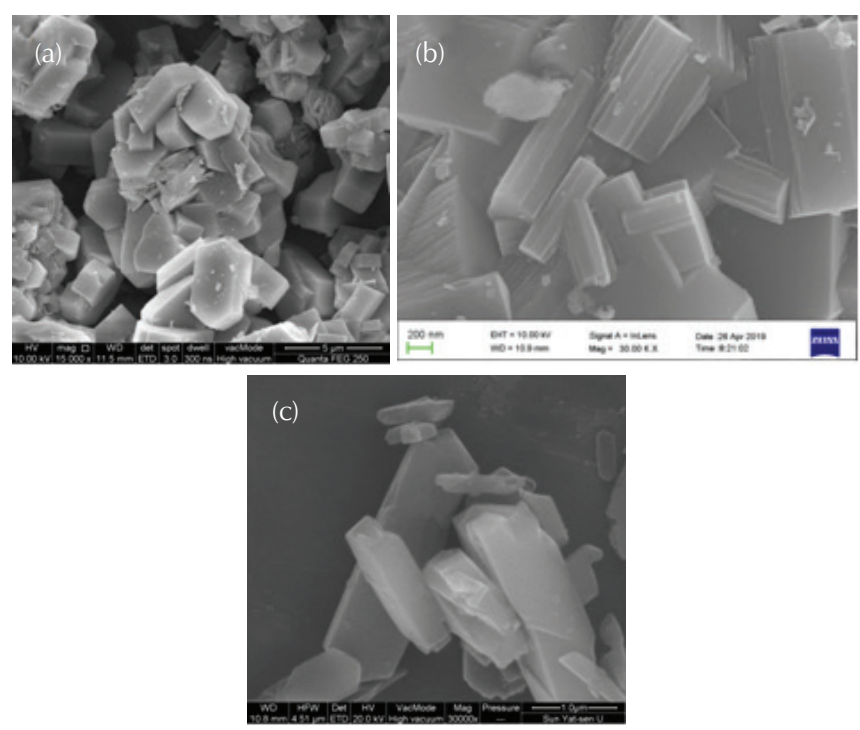

Fig. 4 - SEM images of ZSM-5 molecular sieve (a) IZ, (b) GZ, (c) $\mathrm{CZ}$ 
compared with the ZSM- 5 synthesis by traditional gel technology, the average pore sizes of GZ and IZ were larger, thus revealing the gap between in-situ technology and gel technology. Products from in-situ technology have more mesopores and larger average pore size. The micropore volume of $\mathrm{CZ}$ was larger than that of $\mathrm{IZ}$ and $\mathrm{GZ}$, due to the high content of molecular sieve.

The crystal size and surface morphology of ZSM-5 molecular sieve are shown in Fig. 4 . The particle size of IZ molecular sieve was about $2 \mu \mathrm{m}$, and that of GZ and CZ molecular sieve about $2.5 \mu \mathrm{m}$ and $3 \mu \mathrm{m}$, respectively. Obviously, the ZSM-5 molecular sieve synthesized by the solid phase in-situ method had smoother shape, and crystal size was uniform, which further improved the contact area with reactants.

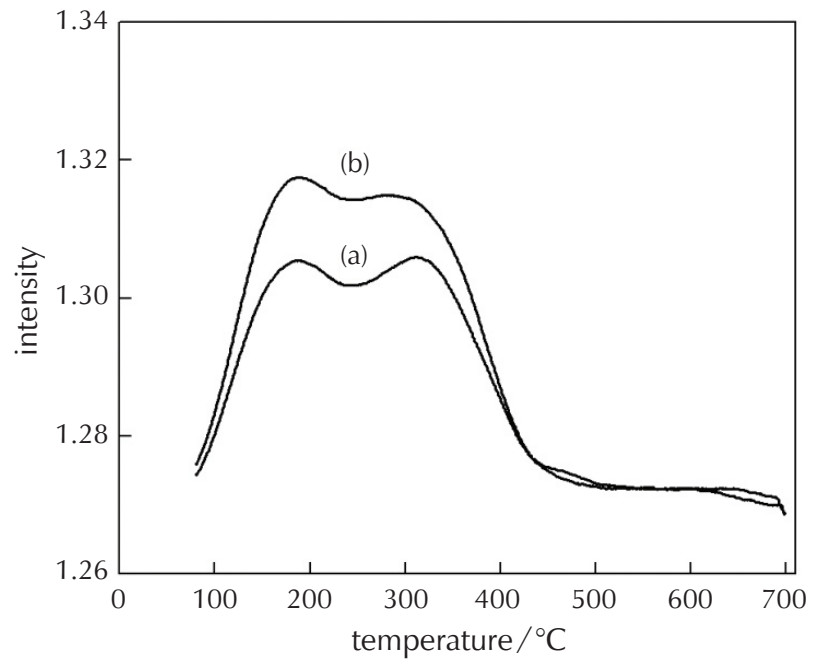

Fig. $5-\mathrm{NH}_{3}$-TPD curves of ZSM-5 molecular sieves (a) IZ, (b) $\mathrm{GZ}$

$\mathrm{NH}_{3}$-TPD curves of ZSM-5 molecular sieves are shown in Fig. 5. In the $\mathrm{NH}_{3}$-TPD curves, both peaks appear at $190{ }^{\circ} \mathrm{C}$ and $315{ }^{\circ} \mathrm{C}$. The desorption peak areas of the two molecular sieves almost coincided at $190{ }^{\circ} \mathrm{C}$, suggesting that the two molecular sieves had the same amount of acid. However, the peak position at $315{ }^{\circ} \mathrm{C}$, clearly showed that the peak area of GZ molecular sieve was larger, and the appearance of low temperature peak was also caused by desorption after ammonia combined with weak acid or Lewis acid, ${ }^{20}$ demonstrating that the molecular sieve synthesized by the solid phase in-situ method had a higher amount of acid. This additionally proves that the solid phase in-situ method is conducive to complete reaction, which increases the effective utilization of resources, and performs better than the traditional hydrothermal method.

\subsection{FCC additive prepared by the GZ molecular sieve}

3.2.1 Physicochemical properties of FCC catalyst additive

The catalytic cracking reaction is affected by the physicochemical properties of FCC catalyst additive. Table 3 shows the physicochemical properties of GCD and ICD FCC catalyst additive for increasing light olefin. The lower attrition index of GCD catalyst additive ensures better stability and longer life. The difference in bulk density of GCD and ICD was very small. More importantly, the surface area and pore volume of GCD additive prepared by solid phase in-situ method were better than those of hydrothermal synthesis products. The reactivity increased because of the larger specific surface area and pore volume, which reduced the diffusion resistance of large molecules, thus preventing a side reaction. Compared to the ICD additive, the MAT of GCD was higher.

Table 3 - Physicochemical properties of FCC catalyst additive

\begin{tabular}{c|c|c}
\hline Catalyst additive & ICD & GCD \\
\hline attrition index $/ \mathrm{m}^{\prime} \mathrm{h}^{-1}$ & 2.1 & 1.8 \\
\hline specific area $/ \mathrm{m}^{2} \mathrm{~g}^{-1}$ & 195 & 201 \\
\hline pore volume $/ \mathrm{ml} \mathrm{g}^{-1}$ & 0.30 & 0.32 \\
\hline bulk density $/ \mathrm{g} \mathrm{ml}^{-1}$ & 0.70 & 0.69 \\
\hline MAT $\mathrm{m} \% / 800^{\circ} \mathrm{C} / 4 \mathrm{~h}$ & 75 & 78 \\
\hline
\end{tabular}

\subsubsection{Evaluation of catalytic performance}

The catalytic performance of catalyst additives was evaluated on ACE. Table 4 reveals that the GCD and ICD catalyst additive had a good selectivity for propylene and butene. The GCD catalyst additive can improve the yield of liquefied petroleum gas (LPG), propylene and butene. Propylene and butene yields increased by 2.28 and $2.15 \mathrm{wt} \%$, respectively, while ICD catalyst additive increased them by

Table 4 - Catalytic performance of FCC additive

\begin{tabular}{c|c|c|c}
\hline Samples & $\begin{array}{c}\text { Base } \\
\text { catalyst }\end{array}$ & $\begin{array}{c}\text { Base catalyst } \\
+ \text { ICD }\end{array}$ & $\begin{array}{c}\text { Base catalyst } \\
+ \text { GCD }\end{array}$ \\
\hline Product yield/wt\% & & & \\
\hline dry gas & 2.23 & 2.31 & 2.27 \\
\hline LPG & 11.21 & 14.72 & 14.95 \\
\hline gasoline & 51.63 & 47.29 & 48.03 \\
\hline LCO & 18.44 & 17.85 & 17.57 \\
\hline HCO & 10.21 & 11.22 & 10.69 \\
\hline coke & 6.28 & 6.61 & 6.49 \\
\hline conversion/wt\% & 71.35 & 70.93 & 71.74 \\
\hline propylene/wt $\%$ & 2.88 & 4.90 & 5.16 \\
\hline butene/wt\% & 3.12 & 5.01 & 5.27 \\
\hline Product selectivity & & & \\
\hline dry gas/conversion & 0.031 & 0.033 & 0.032 \\
\hline LPG/conversion & 0.16 & 0.21 & 0.21 \\
\hline propylene/LPG & 0.26 & 0.33 & 0.35 \\
\hline coke/conversion & 0.088 & 0.093 & 0.090 \\
\hline
\end{tabular}


2.02 and $1.89 w t \%$, respectively. It was noted that the yield of C3-4 olefins of the in-situ FCC catalyst additive was outstandingly higher than that with the base catalyst. Thus, the yield of propylene and butene had significantly increased, indicating that the ZSM-5 molecular sieve was the core active component in increasing the yield of the light olefin. Compared with the ICD additive, the yield of LPG, propylene, and butene with the GCD catalyst additive increased obviously. The results indicate that the GCD catalyst additive prepared by solid phase method has better heavy oil cracking capability and coke selectivity. The good product selectivity and higher LPG yield are obviously related to its wide pore structure and its optimized acidity distribution.

\section{Conclusion}

In this study, the pure ZSM-5 zeolite with high acid content and wide pore structure was successfully prepared by solid-phase in-situ synthesis, and its crystallinity and BET specific surface area were larger than those prepared by traditional in-situ hydrothermal synthesis. The average pore size of $5.8 \mathrm{~nm}$ was much larger than that of commercial molecular sieve, which provided more catalytic activity. On the other hand, the FCC catalyst additive prepared by ZSM-5 molecular sieve for light olefin had better catalytic selectivity. The yields of propylene and butene were $5.16 \%$ and $5.27 \%$ respectively, and the cracking capacity of heavy oil increased significantly, the selectivity of coke had also obviously improved.

\section{ACKNOWLEDGEMENTS}

This work was financially supported by the National Natural Science Foundation of China (No. 21371055), Key Project of Scientific Research Project of Hunan Education Department (No. 18A313).

\section{References Literatura}

1. J. Mi, F. Yuan, J. Zhang, Transition metals-Modified SAPO-34 for methanol conversion to light olefins, 2013 International Conference on Materials for Renewable Energy and Environment, Chengdu, 2013, pp. 721-724, doi: https://doi. org/10.1109/ICMREE.2013.6893778.

2. M. L. da Silva Neto, Use of Supercritical Propylene to Produce Polypropylene/Clay Nanocomposites via in situ Polymerization, UWSpace, 2014, url: http://hdl.handle. net/10012/8412.

3. M. Horák, P. Mach, Study of electrical ageing of polypropylene film capacitors using third harmonics measurement, 2014 IEEE $20^{\text {th }}$ International Symposium for Design and Technology in Electronic Packaging (SIITME), Bucharest, 2014, pp. 55-59, doi: https://doi.org/10.1109/SIITME.2014.6966994.

4. J. G. Speight, Fluid-Bed Catalytic Cracking, Springer Handbooks, 2017, pp. 617-648, doi: https://doi.org/10.1007/9783-319-49347-3 19.

5. A. Primo, H. Garcia, Zeolites as catalysts in oil refining, Chem. Soc. Rev. 43 (22) (2014) 7548-7561, doi: https://doi. org/10.1039/C3CS60394F.

6. J. Weitkamp, Zeolites and catalysis, Solid State Ion 131 (12) (2000) 175-188, doi: https://doi.org/10.1016/S01672738(00)00632-9

7. J. Shi, Y. Wang, W. Yang, Y. Tang, Z. Xie, Recent advances of pore system construction in zeolite-catalyzed chemical industry processes, Chem. Soc. Rev. 44 (24) (2015) 8877 8903, doi: https://doi.org/10.1039/C5CS00626K.

8. C. S. Cundy, P. A. Cox, The Hydrothermal Synthesis of Zeolites: History and Development from the Earliest Days to the Present Time, Chem. Rev. 103 (3) (2003) 663-702, doi: https://doi.org/10.1021/cr020060i.

9. E. T. C. Vogt, B. M. Weckhuysen, Fluid catalytic cracking: Recent development on the grand old lady of zeolite catalysis, Chem. Soc. Rev. 44 (20) (2015) 7342-7370, doi: https://doi. org/10.1039/C5CS00376H.

10. J. Shi, Y. Wang, W. Yang, Y. Tang, Z. Xie, Recent advances of pore system construction in zeolite-catalyzed chemical industry processes, Chem. Soc. Rev. 44 (24) (2015) 88778903, doi: https://doi.org/10.1039/c5cs00626k.

11. N. Masoumifard, R. Guillet-Nicolas, F. Kleitz, Synthesis of engineered zeolitic materials: From classical zeolites to hierarchical core-shell materials, Adv. Mater. 30 (16) (2018) 1704439, doi: https://doi.org/10.1002/adma.201704439.

12. K. Cheng, J. Kang, S. Huang, Z. You, Q. Zhang, J. Ding, W. Hua, Y. Lou, W. Deng, Y. Wang, Mesoporous Beta Zeolite-Supported Ruthenium Nanoparticles for Selective Conversion of Synthesis Gas to C5-C11 isoparaffins, ACS Catal. 2 (3) (2012) 441-449, doi: https://doi.org/10.1021/ cs200670j.

13. L. Ren, Q. Wu, C. Yang, L. F. Zhu, C. Li, P. Zhang, H. Zhang, X. Meng, F.-S. Xiao, Solvent-Free Synthesis of Zeolites from Solid Raw Materials, J. Am. Chem. Soc. 134 (2012) 1517315176, doi: https://doi.org/10.1021/ja3044954.

14. X. Wang, Q. Wu, C. Chen, S. Pan, W. Zhang, X. Meng, S. Maurer, M. Feyen, U. Müllerd, F.-S. Xiao, Atom-economical synthesis of a high silica $\mathrm{CHA}$ zeolite using a solvent-free route, Chem. Comm. 51 (2015) 16920-16923, doi: https:// doi.org/10.1039/C5CC05980A.

15. Y. Ji, B. Zhang, W. Zhang, B. Zhao, H. Li, D. Wang, Y. Li, Highefficient synthesis of zeolite LTA via a wet-gel crystallization route, Chem. Res. Chinese U. 33 (4) (2017) 520-524, doi: https://doi.org/10.1007/s40242-017-7008-y. 
16. F. Pan, X. Lu, Y. Wang, S. Chen, T. Wang, Y. Yan, Organic template-free synthesis of ZSM-5 zeolite from coal-series kaolinite, Mater. Lett. 115 (2014) 5-8, doi: https://doi. org/10.1016/j.matlet.2013.10.007.

17. F. Pan, X. Lu, Y. Wang, S. Chen, T. Wang, Y. Yan, Synthesis and crystallization kinetics of ZSM-5 without organic template from coal-series kaolinite, Micropor. Mesopor. Mater. 184 (2014) 134-140, doi: https://doi.org/10.1016/j.micromeso.2013.10.013.

18. K. Zhang, Y. Liu, J. Zhao, C. Liu, Hierarchical Porous ZSM-5 Zeolite Synthesized by in situ Zeolitization and Its Coke
Deposition Resistance in Aromatization Reaction, Chinese J. Chem. 30 (3) (2012) 597-606, doi: https://doi.org/10.1002/ cjoc. 201100217.

19. Y. Liu, S. Han, D. Guan, S. Chen, Y. Wu, Y. Yang, N. Jiang, Rapid green synthesis of ZSM-5 zeolite from leached illite clay, Micropor. Mesopor. Mater. 280 (2019) 324-330, doi: https://doi.org/10.1016/j.micromeso.2019.02.027.

20. F. Lónyi, J. Valyon, A TPD and IR study of the surface species formed from ammonia on zeolite $\mathrm{H}$-ZSM-5, H-mordenite and H-beta. Thermochim. Acta 373 (1) (2001) 53-57, doi: https://doi.org/10.1016/S0040-6031(01)00458-0.

\section{SAŽETAK \\ Zelena sinteza i primjena zeolita ZSM-5 \\ Ou Chen, a Si-Cheng Liu, a Pei-Qing Zhang a i Shu-Qin Zhenga,b,*}

Istražen je kompozit molekularnog sita ZSM-5 sa širokim porama pripremljen sintezom na krutoj fazi in situ i katalitičkim krekiranjem u vrtložnom sloju (FCC) te aditiv katalizatora FCC pripremljen istim molekularnim sitom ZSM-5 u svrhu povećanja količine prinosa lakog olefina. Uzorci su karakterizirani rendgenskom difrakcijom na prahu (XRD), adsorpcijom/desorpcijom $\mathrm{N}_{2}$, skenirajućim elektronskim mikroskopom (SEM) te temperaturno programiranom desorpcijom amonijaka $\left(\mathrm{NH}_{3}\right.$-TPD). Rezultati su pokazali da je struktura smjese molekularnog sita ZSM-5 pripremljena metodom sinteze in situ u čvrstoj fazi čisti zeolitni materijal skupine MFI. Kristaliničnost molekularnog sita ZSM-5 iznosila je 59,8 \%. Sintetizirano molekularno sito ZSM-5 imalo je više kiseline i strukturu sa širokim porama. Prosječna veličina pora bila je 5,9 nm, a specifična površina (BET) i specifična površina mikropora uzoraka iznosile su $213 \mathrm{~m}^{2} \mathrm{~g}^{-1}$, odnosno $124 \mathrm{~m}^{2} \mathrm{~g}^{-1}$. Evaluirani rezultati ukazali su na to da aditiv katalizatora FCC pokazuje dobru selektivnost za ukapljeni naftni plin (UNP), propilen i buten, povećavajući prinos propilena i butena za 2,28 \%, odnosno 2,15\%, kao i da ima bolju sposobnost krekiranja teškog ulja i selektivnost koksa.

\section{Ključne riječi}

Zeolit ZSM-5, tehnologija in situ, metoda sinteze na krutoj fazi, aditiv katalizatora FCC, povećanje prinosa lakog olefina

\footnotetext{
a Department of Chemistry and Chemical Engineering, Hunan Institute of Science and Technology, Yueyang 414 006, Hunan, Kina

${ }^{\mathrm{b}}$ Hunan Province Key Laboratory of Speciality Petrochemicals Catalysis and Separation, Yueyang 414 000, Hunan, Kina
}

Izvorni znanstveni rad Prispjelo 27. svibnja 2020. Prihvaćeno 4. rujna 2020. 